\title{
Whole-person care: Our foundation, our future
}

I $\mathrm{n}$ this issue of The Journal of Family Practice, Dr. Wayne Jonas explains his model for Advanced Primary Care (see page 493). The figure he uses to illustrate Advanced Primary Care is compelling, and the effectiveness of this model of health care is supported by a great deal of research and evaluation over the past 20 years. Let me provide some historical context.

The idea that healing requires more than curative, biology-based medical care dates back to Greek mythology. Asclepius, the god of medicine, had 5 daughters, Hygeia (the goddess of good health and hygiene), Iaso (cures and remedies), Aceso (healing wounds), Aegle (radiant good health), and Panacea (cures). ${ }^{1}$ Clearly, the

\section{We can no longer go "halfway" into whole-person care.} Greeks believed that integrative care is essential for maintaining good health!

Modern, scientific medicine is a relatively recent development in human history. Other traditions of healing such as acupuncture and herbal medicines are actually much older than mainstream Western medicine. But they come together in family medicine-a specialty founded on the principles of whole person, whole family, and whole community care.

The first modern model of comprehensive care, the patient-centered medical home (PCMH), was introduced by the American Academy of Pediatrics in 1967. This idea caught on widely and was institutionalized by the National Committee for Quality Assurance in 2008 with PCMH certification.

Advanced Primary Care is the latest and best rendition of comprehensive primary health care. Funding this model through our current payment mechanisms, however, has been difficult because of the need to support social and behavioral interventions in addition to medical care-areas of care not traditionally paid for by medical premiums. In 2011, CMS collaborated with private insurers in a national demonstration project to test the financial feasibility of implementing Advanced Primary Care. Some organizations have been highly successful; others not as much.

We can no longer go "halfway" into whole-person care. The COVID-19 pandemic has put a spotlight on our need to transform payment models away from fee-forservice to reimbursement for whole person primary care. Our nation's health and the viability of our health care system depend on it.
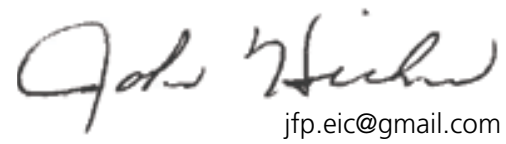

PS: I recommend reading Dr. Jonas' book, How Healing Works, which provides a scientific rationale for the application of whole-person care to healing.

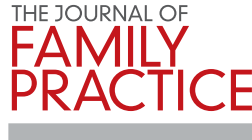

EDITOR-IN-CHIEF JOHN HICKNER, MD, MSC

Professor Emeritus

Michigan State University

College of Human Medicine

ASSOCIATE EDITOR

RICHARD P. USATINE, MD

University of Texas Health

at San Antonio (Photo Rounds)

ASSISTANT EDITORS DOUG CAMPOS-OUTCALT, MD, MPA University of Arizona

RICK GUTHMANN, MD, MPH Advocate Illinois Masonic Family Medicine Residency, Chicago

ROBERT B. KELLY, MD, MS Fairview Hospital, a Cleveland Clinic hospital GARY KELSBERG, MD, FAAFP University of Washington, Renton COREY LYON, DO University of Colorado, Denver KATE ROWLAND, MD, MS Rush-Copley Medical Center, Chicago E. CHRIS VINCENT, MD University of Washington, Seattle

EDITORIAL BOARD FREDERICK CHEN, MD, MPH University of Washington, Seattle
Unitis JEFFREY T. KIRCHNER, DO, FAAFP, AAHIVS Lancaster General Hospital, PA

TRACY MAHVAN, PHARMD University of Wyoming, Laramie MICHAEL MENDOZA, MD, MPH, MS, FAAFP University of Rochester, NY

FRED MISER, MD, MA The Ohio State University, Columbus KEVIN PETERSON, MD, MPH University of Minnesota, St. Paul MICHAEL RADDOCK, MD The MetroHealth System, Cleveland, $\mathrm{OH}$ MICHELLE ROETT, MD, MPH, FAAFP, CPE Georgetown University Medical Center, Washington, DC

KATE ROWLAND, MD, MS Rush-Copley Medical Center, Chicago

LINDA SPEER, MD

University of Toledo, $\mathrm{OH}$

DIRECT INQUIRIES TO: Frontline Medical Communications 7 Century Drive, Suite 302 Parsippany, NJ 07054 Telephone: (973) 206-3434 Fax: (973) 206-9378 